Draft - 29 June 2010

\title{
Australia and India: the Indian Ocean and the limits of strategic convergence
}

\section{David Brewster}

\section{Introduction}

In November 2009, Australia and India announced a Joint Declaration on Security Cooperation, intended to set out shared strategic perspectives and create a framework for the further development of bilateral security cooperation. At the same time, former Prime Minister Rudd told an audience in New Delhi that India and Australia were "natural partners" and should become "strategic partners" (Rudd 2009). Rudd's comments reflect a common assumption that the strategic perspectives of Australia and India are inexorably converging and there is no reason why they will not become close economic, political and security partners in the coming years. This article tests that view and considers some potential conflicts in strategic interest that may require careful management as India extends its power in the Indian Ocean.

The Indian Ocean is taking an increasingly prominent place in Australia's security calculations. While Australia's traditional security focus has been towards Southeast Asia, since 1973 virtually all of Australia's military engagements (including in Kuwait, East Timor, Iraq and Afghanistan) have been in the Indian Ocean region and there is reason to believe that this will continue. As Australia's 2009 Defence White Paper stated: "Over the period to 2030, the Indian Ocean will join the Pacific Ocean in terms of its centrality to our maritime strategy and defence planning." (Australia 2009: 37)

This article will discuss the potential limits of strategic convergence between Australia and India with particular reference to the Indian Ocean. It will first provide an overview of recent developments in the strategic relationship. It will then review perceptions of strategic convergence between Australia and India. Third, it will examine India's naval ambitions in the Indian Ocean. Fourth, this article will consider how India's maritime ambitions have the potential to diverge from Australia's interests. It will conclude that 
these potential differences in interest reinforce the imperatives for, and underline some of the difficulties in, Australia's strategic engagement with India.

\section{Recent developments in the Australia - India relationship}

Australia's security relationship with India has long been uneasy. However, the relationship has certainly come a long way, particularly since 1998 when Australia (along with Japan) led international condemnation of India's Pokhran II nuclear tests. Recent improvements in the relationship have largely been in step with improvements in India's the security relationship with the United States, capped by the recent nuclear cooperation agreement under which the United States effectively recognized India as a de facto nuclear power. As part of India's Look East Policy, since the early 1990s India has also been seeking to develop economic, political and security relationships throughout East Asia, most particularly with Japan, Singapore and Vietnam. These relationships are driven by a common interest to balance China's rising power in East Asia and a desire on the part of India to extend its influence as a regional power. For India, in many ways the relationship with Australia is an extension both of its Look East Policy and of its growing relationship with the United States.

The security engagement between Australia and India has gained some momentum over the last few years, primarily at Australia's initiative. Australian prime ministers have made several visits to New Delhi in the last decade and there have been numerous ministerial level engagements. This has led to several bilateral agreements on security-related matters, including a 2003 agreement on terrorism, a 2006 memorandum of understanding on defence cooperation, a 2007 defence information sharing arrangement and agreements on intelligence dialogue, extradition and terrorism in 2008. Australia's 2009 Defence White Paper flagged the "strong mutual interest" of Australia and India in enhancing maritime security cooperation in the Indian Ocean, commenting that, "As India extends its reach and influence into areas of shared strategic interest, we will need to strengthen our defence relationship and our understanding of Indian strategic thinking..."(Australia 2009: 96) 
In November 2009, the Australian and Indian Prime Ministers announced a Joint Declaration on Security Cooperation. The Security Declaration is a non-binding declaration of principles and understandings in security matters and establishes a bilateral framework for further cooperation in security matters (Brewster 2010a). Australia also has similar Security Declarations with Japan (in 2007) and South Korea (in March 2009). Although the AustraliaIndia Security Declaration itself contains little new of substance, it is a notable step in establishing a framework for the further development of the security relationship, including the formalisation of regular consultations and dialogues between foreign ministers, senior military and diplomatic representatives and joint working groups on maritime security operations and counter-terrorism and immigration. In conjunction with the Security Declaration, Australia and India finalised new cooperation arrangements in intelligence, law enforcement, border security, terrorist financing and money laundering. Australia has also sought to encourage greater interaction between the defence forces, including inviting India to participate in the Australian-hosted multilateral Kakadu and Pitch Black exercises in northern Australia.

While bilateral security cooperation is developing, both Australia and India have been cautious about giving the relationship broader strategic significance, particularly in allowing it to be perceived as anything that might resemble a coalition against China. In 2007, Japan proposed a "Quadrilateral" dialogue among it, India, the United States and Australia. Despite official denials, this was viewed by many as part of a policy to balance or contain China and by some as the beginnings a four-way alliance. These perceptions were reinforced by the large-scale Malabar 2007 naval exercises held later that year in the Bay of Bengal, involving India, the United States, Australia, Japan and Singapore. Over the course of 2007 , both Australia and India backed away from participation in the Quadrilateral dialogue, largely in the face of concerns about China's reactions.

Despite the recent Security Declaration, the political relationship also remains somewhat uneasy, and there are several ongoing irritants in the relationship. This most significant in security terms has been the nuclear issue, where Australia, for domestic political reasons, has not yet been able to fully accommodate new India's status as a nuclear power outside of 
the nuclear non-proliferation regime. Although Australia supported approval of the USIndian nuclear deal by the Nuclear Supplier's Group in August 2008, its continuing refusal to supply uranium to India is inevitably taken as indicating a lack of commitment to the relationship.

\section{Perceptions of strategic convergence between Australia and India}

Australian security analysts strongly support a closer security engagement between Australia and India, apparently seeing few conflicts of strategic interest. Many agree with Mr Rudd that Australia and India are "natural" strategic partners. With the end of the Cold War and the strategic rapprochement between India and the United States, it is widely believed that the gates are now open for Australia and India to recognize their shared perspectives and build a close strategic partnership reflecting common interests in such matters as terrorism, maritime security and regional security architecture.

Gurry in her detailed review of the history of the relationship since the end of World War II, describes the long-standing strategic estrangement between Australia and India as a failure to establish a common purpose and shared perspective. According to Gurry, this is essentially the result of a number of "unfortunate" historical factors, including differing Cold War alignments, inaccurate or out of date perceptions on both sides and a lack of complementarity of commercial goals (Gurry: 1995; Gurry 1996). According to Gurry, the end of Cold War alignments, closer economic relations and a little political foresight will allow this situation to be remedied.

Gordon also sees the Australia-India relationship in benign terms. Gordon suggests that Australia and India are on the same basic 'strategic wavelength"' although Australia has to be careful to explain to New Delhi the nuances of its relationships with the United States and China so that India will recognize Australia as an independent player in the region (Gordon 2007: 50). Similarly, Medcalf sees Cold War "circumstances" as having obstructed closer engagement between Australia and India and that they are "logical strategic partners." (Medcalf 2008b). According to Medcalf the geostrategic interests of the two 
countries as "essentially congruent. Neither sees the other as a potential security problem, and indeed they openly recognize each other as factors for stability in their shared region" (Medcalf and Gill 2009). Bonnor takes a somewhat more cautious view of the relationship, commenting that Australia and India have limited bilateral security interests in common and that although these are not of enormous weight in each country's strategic outlook. However, "given geographical proximity across a common ocean, at the very least it would be beneficial for Australia and India to better understand each other's security perceptions and preoccupations." (Bonnor 2001: 13-4).

Few Indian security analysts give detailed consideration to Australia. Australia is broadly seen as an element in India's Look East Policy, although not having the priority afforded to India's relations in Southeast Asia and Japan. Some such as Brahma Chellaney see Australia as a potentially useful junior partner along with the United States and Japan in an informal coalition to balance against China (Chellaney 2007). Others such as C.Raja Mohan who oppose the idea of any coalition against China, nevertheless define Indo-Australian common interests in terms of building an Asian order that addresses mutual concerns about China. (Mohan 2007). In general however, Australia is perceived to have little to offer India beyond natural resources and it is assumed that Australia will always follow the US lead in security matters. Thus there is little perceived imperative to engage with Australia or any real sense that India should take Australia's opinions into consideration, particularly when making judgments about China or the Indian Ocean (Copley 2009: 127).

Australian analysts commonly cite areas in which there is significant scope for bilateral security cooperation, such as in maritime policing (piracy and maritime terrorism, illegal fishing, people trafficking etc) and disaster management in the eastern Indian Ocean and anti-terrorism throughout the region. In the political-security arena, Australia and India are likely to have significant shared interests in ensuring that any future Asian regional architecture includes both India and Australia, two outliers from the core of East Asia. Australia and India also have shared interests in the political stability in South Asia (Afghanistan, Pakistan) and Southeast Asia (particularly Indonesia). There may also be scope for cooperation on particular issues such as nuclear non-proliferation and 
disarmament (Medcalf and Gill 2009). Underlying this is a strong incentive in Australia to see India becoming a major investor in its resources sector to match other major investors such as China. India also has good reason to want to develop Australia as a major energy supplier.

There is much to be said for views on the scope for increased security cooperation and a perceived imperative for Australia to better engage with one of Asia's giants. For many it is a surprise that two neighbours, with common democratic values and a shared heritage in political and legal institutions, have never found good reason to cooperate closely in political, economic and security issues. It is therefore natural to identify "exogenous" factors (such as differing Cold War alignments) that have historically kept Australia and India apart. However, this analysis often also fails to consider the existence of underlying differences of interest that might have contributed to the long estrangement between Australia and India. This article will argue that underlying differences of interest have existed and there are strong reasons for Australia to be actively engaged as India emerges as one of the major powers of Asia and moves beyond its historical preoccupations in South Asia.

\section{India's strategic ambitions in the Indian Ocean}

While a continentalist perspective has traditionally dominated Indian strategic thinking, maritime security has an increasing role in India's calculations. Driven by ideas of its own "manifest destiny" and a developing strategic rivalry with China, India has over the last two decades been expanding its naval power in the Indian Ocean.

India occupies a highly strategic position in the northern Indian Ocean, potentially allowing it to control the key sea lines of communication to and from the Suez Canal, the Persian Gulf and the Malacca Strait. According to the Indian Navy's 2004 Maritime Doctrine: "By virtue of geography, we are... in a position to greatly influence the movement/security of shipping along the [sea lines of communication] in the [Indian Ocean region] provided we have the maritime power to do so. Control of the choke points could be useful as a bargaining chip in 
the international power game, where the currency of military power remains a stark reality." (Indian Navy 2004: 64).

India's central position in the northern Indian Ocean and its presumed future as a great power contribute to a commonly held view about India's destiny to attain a dominant role in its eponymous ocean. K.M. Panikkar, the "father" of Indian maritime strategy, argued that the Indian Ocean must remain "truly Indian," and advocated the creation of a "steel ring" around India through the establishment of forward naval bases in Singapore, Mauritius, Yemen and Sri Lanka. There is a reportedly "well established tradition" among Indian navalists that the Indian Ocean is, or should be, "India's Ocean" (Scott 2006: 99; Berlin 2006: 60). According to Admiral Prakesh, Indian Chief of Naval Staff: "India holds the centre stage in the only ocean in the world named after a country." (Prakesh 2006).

India is in the process of significantly enhancing its naval power projection capabilities. The navy's share of the defence budget has risen significantly. According to Prakesh, India aims to exercise selective sea control of the Indian Ocean through task forces built around aircraft carriers. (Prakesh 2006). India, which currently has a single aging aircraft carrier, has plans for three carrier task forces that will form the core of three separate fleets in the Bay of Bengal, the Indian Ocean and the Arabian Sea. Buszynski believes that India's naval expansion program, if fully implemented, would place it in a dominant position in the Indian Ocean, although the program will depend on adequate funding in the years to come (Buszynski 2009: 84). This last point is important. India has a long tradition of its strategic ambitions surpassing its capabilities, of strategic goals and military expansion plans going unfulfilled, reflecting its impatience to be recognized as a great power combined with a long-standing lack of co-ordination in strategic planning. Varun Sahni, for example, has described the Indian navy's plans as "an inflated vision of naval threats and capabilities" in India leading to over-ambitiousness in pursuing a strategy of sea control around aircraft carriers over a strategy of sea denial centred on submarines. Sahni warns: "The mothballed [Soviet] vessels from Archangel to Sevastapol to Vladivostok are a grim warning of what happens to a continental state that harbours overly grandiose maritime ambitions" (Roberts and Sahni 2005: 25). 
India's naval ambitions extend to developing an Indian sphere of influence across the northern Indian Ocean. This should be no surprise. Realists argue that it is natural for especially powerful states to seek regional hegemony. One study of India's regional plans concluded that: "a rising India will try to establish regional hegemony in South Asia and the Indian Ocean Region... just like all the other rising powers have since Napoleonic times, with the long term goal of achieving great power status on an Asian and perhaps even global scale." (Pardesi 2005: 55). Many believe that since independence India has sought to impose its own "Monroe Doctrine" on South Asia, and some suggest that there are now ambitions to extend this across the Indian Ocean (Holmes and Yoshihara 2008b). The Indian Navy has come to see itself as destined to become the predominant maritime security provider in a region stretching from the Red Sea to Singapore and having a significant security role in areas beyond, including the South China Sea (Scott 2006). This is an area which the former Indian Foreign Minister Jaswant Singh called India's sphere of influence (Times of India, 13 April 2001) and the current Prime Minister has called India's strategic footprint (Singh 2004). While India's strategic ambitions are primarily focused on northern Indian Ocean, India has also made significant progress in developing maritime security partnerships with island states in the central and southern Indian Ocean including with the Maldives, Mauritius and Madagascar (Brewster 2010b).

India's ambitions for predominance in the Indian Ocean region underpin its security ambitions in Southeast Asia. Over the last two decades, the Indian Navy has played an active role in extending India's influence throughout the Indian Ocean region and maritime Southeast Asia (Scott 2007). India has placed significant emphasis on achieving a predominant position in the Bay of Bengal and the western approaches to the Malacca Strait, including through the development of military facilities in the Andaman Islands as the base for a new tri-service Andaman \& Nicobar Command. It has been suggested that for India the Malacca Strait represents a rough counterpart to the importance of the Panama Canal to the United States in terms of its ability to maintain regional hegemony (Holmes et al 2009: 154). The Malacca Strait lies on the major sea line of communication and 
represents the main choke point between the Pacific and Indian Oceans. Indian's ability to control the Strait is seen as a prerequisite of effective control of the eastern Indian Ocean. India is now seeking a direct security role inside the Strait, an important factor underlying India's strategic relationships with both Singapore and Indonesia.

Strategic competition with China has been an important factor for India's attempts to consolidate and expand its maritime security role in the Indian Ocean. While some see the "China factor" as a convenient justification for India's naval procurement program, it also carries with it the potential to fuel confrontation between India and China in the Indian Ocean and even the South China Sea. Since the early 1990s, many Indian military leaders and analysts have repeatedly raised concerns about a perceived Chinese plan of maritime "encirclement" of India through China's so-called "String of Pearls" strategy.[1] This has included claims of Chinese involvement in the construction of deep water ports in Pakistan, Burma, Bangladesh, Sri Lanka, the establishment of a Chinese military listening or communications facilities in Pakistan and Burma and an attempt by China to construct a submarine base in the Maldives.[2] China's relationships in the Indian Ocean region are perceived among many Indian analysts as being directed against India rather than being a legitimate reflection of Chinese interests in its sea lanes of communication across the Indian Ocean. The instincts of many in New Delhi are to try to exclude China from the Indian Ocean, just as India sought to exclude the superpowers from the Indian Ocean in the 1970s. The expansion of India's naval capabilities, the increase in India's presence around the Malacca Strait, the attempts to form exclusive security relationships with Indian Ocean island states and the exclusion of China from regional fora, such as the Indian-sponsored Indian Ocean Naval Symposium (Indian Express, 21 April 2009) are all responses to China's perceived "intrusion" into the Indian Ocean.

Over the last decade or so, the United States has played a significant role in India's strategic ambitions. In March 2005, the Bush administration announced that it would help India become a major world power in the 21st century, seeking to build India's capabilities as an implicit balance to China. As a senior US official in New Delhi put it: "India as a global power is in an early, formative phase. The United States' job for the next 5 to 10 years is to 
promote, assist and shape that process." (Twining 2007: 82). Since the 1990s much of the US focus in the relationship has been in encouraging India's naval ambitions and expansion of its naval capabilities, including calling for India to coordinate its maritime strategy with the United States in the Persian Gulf, Southeast Asia and as far as the Taiwan straits (Tellis 2002: 262-3). In 2001, Secretary of State Designate, Colin Powell told the US Senate Foreign Relations Committee, "... India has the potential to help keep the peace in the vast Indian Ocean area and its periphery. We need to work harder and more consistently to help them in this endeavor..." (Washington File 2001). Similarly, US Secretary of the Navy, Donald Winter, commented in 2008, the United States welcomed India "taking up the responsibility to ensure security in this part of the world" (Dikshit 2008). (By "this part of the world," the US does not necessarily the Persian Gulf where the US has been reluctant to allow India a prominent security role.)

The United States has given particular encouragement to India to increase its naval presence in the northeast Indian Ocean (including building the Andaman Island naval base) and has indicated that it would be happy to see India take a direct security role inside the Malacca Strait. In 2006, the commander of the US Pacific Fleet, Admiral Roughead, commented that that the United States was "not interested" in patrolling the region, while, according to the Chairman of the US Joint Chiefs of Staff General Pace, the United States was "very comfortable with the fact that India has offered its assistance" in providing security in the Strait (India Defence 7 June 2006). Much (but not all) of this is a reflection of a desire by the United States to build India as an important balancing factor against China, particularly in the Indian Ocean region. The United States has an incentive to play India and China off against each other and in recent years may have encouraged Indian fears of Chinese naval power in the Indian Ocean.[3]

Japan too, may be willing to recognize a leading naval role for India in the Indian Ocean. Many in Japan see the evolving security relationship with India primarily in terms of a maritime coalition. For Japan, the most immediate benefit of a security relationship with India is its ability to provide maritime security to Japan in the Indian Ocean in combination with or, potentially, as an alternative to the United States. As the former Chairman of Joint 
Staff of the Japanese Defence Agency, Admiral Natsukawa, commented in 2006, "Only India has the capability and intention for security cooperation in [the Indian Ocean] this huge sea area, the west side of the Malacca Strait" (Natsukawa 2006).

\section{Australian perspectives on India's ambitions in the Indian Ocean region}

Australia is likely to be less willing to recognize any Indian claims of a "predominant" maritime role in the Indian Ocean in the northeast Indian Ocean. Australian concerns about India's naval ambitions are not new. During the late 1980s and early 1990s, portions of the Australian security community showed considerable (if unspecified) apprehensions about India's naval modernization and expansion program. These concerns were motivated not only by India's security relationship with the Soviet Union but also by unease about India's own intentions in the region which, it was perceived, India had not adequately explained. Some claim that Australian political considerations were also a significant factor (Huxley 1992). India was highly sensitive to Australian comments which were seen as potentially obstructing India's efforts to improve relations in Southeast Asia. The Australian government sought to defuse the controversy, with Minister of Defence, Kim Beazley stating that India "has never and does not threaten Australia," although he called India's plans "intriguing" (Beazley 1988). Although India was largely successful in dispelling regional concerns about its naval expansion program during the early 1990s, a degree of friction between Australia and India over maritime security continued for several years.[4]

In contrast to the fears expressed during the 1980s, an expansion of India's naval capabilities, particularly in maritime policing functions, is now widely seen in Australia as enhancing Indian Ocean security. Nevertheless, concerns remain regarding India's ambitions in the region.

\section{India as a residual legatee of US naval power in the northeastern Indian Ocean}

One possible way of understanding India's naval ambitions in the Indian Ocean, and the role of the United States in facilitating those ambitions, is in seeing India as a potential residual 
legatee of US naval predominance in the Indian Ocean following any future reduction in the US presence. According to this view, the United States may in the future be willing to cede to India a role as the leading maritime security provider in the northeastern Indian Ocean in the context of the relative decline in US military power throughout the world and as more pressing security concerns arise elsewhere. Some have compared this to the late nineteenth/early twentieth century handover by Britain to the United States of primary responsibility for maritime security in the Western Hemisphere and its ceding of a leading maritime security role to Japan in the Pacific, as Britain focused its energies in balancing against the maritime threat posed by Germany in the North Atlantic (Holmes et al 2009).

What might be the consequences of this for Australia of such a development? Some might see significant benefits to Australia in arrangements between the United States and friendly regional powers over maritime security. However, Australia's last experience in seeing its strategic guarantor delegate or hand over regional security to another power was not a happy one. As noted above, in the early years of the twentieth century, Britain sought to leverage its maritime power in the Pacific and Indian Oceans through entering into a naval alliance with Japan, allowing Britain to largely withdraw its naval forces from the region. As a result, during World War I, the Japanese navy took a leading role in protecting Australian troop convoys against German maritime threats in the Indian Ocean and in expelling Germany from its Pacific possessions.

Between 1902 and 1922, Australian perspectives on the Anglo-Japanese alliance wavered between support and opposition. The Australians saw considerable tactical benefits in the arrangement in protecting sea lanes of communication in the Indian and Pacific Oceans and, it has been suggested, longer term strategic benefits in channeling Japanese expansionism away from Australia and towards China. However, these perceived benefits were balanced by concerns about implications of the alliance on Asian immigration, fears about Japan's seizure of Germany's Pacific possessions and, most importantly, the impact of the alliance on Britain's long term security commitment to the region (Hirama 2004; Lowe 1997). The alliance had the long lasting effect on the balance of naval power in the Pacific, facilitating Japan's rise as the predominant naval power in the Western Pacific, supported by a string of 
naval bases acquired from Germany. The alliance helped propel a revisionist Japan into great power status, emboldening its ambitions in East Asia and the Pacific.

Few, if any, would suggest that an emerging and democratic India has similar expansionist and imperialist tendencies as those displayed by a rising and authoritarian Japan in the first half of the twentieth century. As Beazley commented in 1988, there is no real threat perception about India in Australia and it is hard now to think of circumstances where India might constitute a realistic threat to Australia. Nor is there a suggestion that the United States might contemplate a wholesale abandonment of the Indian Ocean in the same way that Britain abandoned the Pacific. The strategic imperatives for the United States in the Middle East would seem to guarantee a significant US naval presence for the foreseeable future.

However, Australia's experience with Japan in the first half of the twentieth century remains an obvious lesson about the risk that may arise when Australia's security guarantor makes arrangements with rising regional powers without the close involvement of Australia. The issue for Australia is one of appropriate management of changes in the balance of power and accompanying expectations. Australia would, for example, have significant concerns if India's regional ambitions included a failure to accept the legitimate interests in the Indian Ocean of littoral states and extra-regional powers. India has generally shown sensitivity to the interests of other littoral states, but less sensitivity towards the interests of extraregional powers, particularly China. Of particular concern would be if India's ambitions further fed China's existing security dilemma, leading to heightened rivalry between India and China in the Indian Ocean.

Australia is of course much better placed in the early twenty-first century than it was in early twentieth century to play an active role in managing its security environment. During the 1970s, Australia went to considerable efforts in managing its relationship with the United States to ensure the continuation (and expansion) of the US security presence in the Indian Ocean. [Australia may now find its interests in managing the relationshiphe Indo-US strategic relationship to ensure that its interests are properly reflected. ] 


\section{Australian perspectives on India - China naval rivalry}

A key area of concern for Australia in the Indian Ocean in coming years is the potential for naval rivalry between India and China. While some in Australia see the "China threat" as a key factor in the Australia - India security relationship (see e.g. Sheridan 2007), there are, and likely will continue to be, significant differences in Australian and Indian perceptions of China's role in regional security. Although Canberra has remained publicly silent on claims about the "String of Pearls," Australian analysts have tended to treat Indian claims with a considerable degree of skepticism, disputing the nature of Chinese involvement in the Indian Ocean region and China's motivations. Some regard Indian claims about China's "String of Pearls" in the northeast Indian Ocean as exaggerated (Gordon 2007: 4; Buszynski 2009: 86). Selth's detailed analysis of Indian claims about Chinese military facilities in Burma concluded that it is unlikely that any Chinese military personnel are permanently based in Burma or directly operate any intelligence collection stations there (Selth 2007). Australian analysts also tend to see any Chinese presence in the Indian Ocean less in terms of an encirclement of India and more as an expression of China's legitimate interests in protecting its key trading routes to the Middle East and Europe (see, e.g. Copley 2009: 101). There are also significant doubts about China's ability to project and maintain significant power into the Indian Ocean (see e.g. Buszynski 2009: 77).

From Australia's perspective, the prospect of heightened naval rivalry in the eastern Indian Ocean or the South China Sea would be viewed seriously. Some of India's actions, including the development of Indian naval capabilities in and around the Malacca Strait, will only serve to worsen China's security dilemma in the Indian Ocean. Further, any significant projection of Indian naval power into the South China Sea (for example from port facilities in Singapore or Vietnam) would almost certainly be seen as highly provocative by China and destabilizing to regional security. Certainly there seems to be a need for some new thinking in this area. The respected Indian maritime strategist, K.M. Panikkar, long ago recognized the adverse impact on regional security of China's strategic dilemma in the Indian Ocean, going so far as to suggest that Rangoon should be turned into a "free port" for trading by 
China on the Indian Ocean (Panikkar 1943: 105). The recent suggestion by the junior Indian Defence Minister that India might provide maritime security to Chinese ships in the northwest Indian Ocean (People's Daily, 23 February 2010) involves an important acknowledgement by New Delhi that China does have legitimate security concerns in the Indian Ocean. The incoming Indian National Security Advisor, Shiv Shankar Menon, has taken a more ambitious approach, suggesting the discussion of collective security arrangements among the "major powers concerned in the Indian Ocean" in order to minimise the risk of interstate conflict and threats from piracy and terrorism. Importantly, according to Menon, Indian Ocean given the trading routes across the Indian and Pacific Oceans, the security of the two oceans cannot be considered in isolation: "...what is suggested is a real concert of Asian powers, including the USA which has a major maritime presence and interests in Asia, to deal with issues of maritime security in all of Asia's oceans. As Asia becomes more integrated from Suez to the Pacific, none of Asia's seas or oceans can be considered in isolation." (Menon 2009) This suggestion, though positioned as "unofficial," could be a significant step in seeking to resolve the Sino-Indian security dilemma in the Indian Ocean region.

It is not entirely clear what role Australia could play in addressing this problem. Bonnor suggests that rather than tilting toward one side or another, Australia's interests are in working with both India and China in shaping Asia's future security order to accommodate the demands of both and the legitimate interests of other regional powers. (Bonnor 2008: 168). Australia might conclude, for example, that it is in its interests to facilitate China's role as a responsible stakeholder in the Indian Ocean (e.g. through allowing China a voice in issues relating to the Indian Ocean in fora). As the Australian Defence White Paper notes, Australia needs to engage China as a responsible stakeholder in areas "close to home" (Australia 2009: 95). This should include in the Indian Ocean region.

\section{Some considerations in Australia's security engagement with India}

There are many obvious areas of common interest between Australia and India, including terrorism, maritime policing and disaster management. Both have strong interests in the 
political stability of South Asia and Southeast Asia and share a strong interest in seeing the development of "balanced" multilateral economic, political and security institutions in Asia. The Security Declaration was a notable step in creating a framework for further interaction, particularly in relation to the small "s" security issues. However, there are several potential sources of difficulty in the relationship:

First, we should expect continuing irritations in the relationship - for several reasons. Arguably, there are inherent difficulties in building a productive relationship between Australia and an emerging power with great power aspirations such as India. An active middle power such as Australia is neither a major regional power (such as Japan) that is inherently important to India nor a small and useful "gateway" state (such as Singapore). As an emerging power, India is also particularly demanding of recognition of its major power status, an issue which arguably underlies India's strong reactions on the issues of uranium sales, Indian students and likely future instances where Australia may be perceived as not showing proper respect. While there has been recognition of the potential for security cooperation, arguably, there is no mutual understanding that each is a crucial element in the other's security. This is compounded by a view in New Delhi that Australia is not an "independent" strategic actor due to its relationship with the United States. Why deal with Canberra when one can deal with Washington? In short, other than as a potential energy supplier, Australia will find it difficult to make itself an "indispensible partner" to India.

Second, Australia will need to navigate carefully in its relationships with India and China. Australia cannot place itself in a position where it must choose "between" China and India, whether in Southeast Asia or the Indian Ocean. As the short-lived Quadrilateral initiative demonstrated, it would be a mistake to frame Australia's relationship with India within any China threat theory. While perspectives on China in New Delhi are much more varied and nuanced than some believe, they are still quite a distance from Canberra's. China is, after all, continuing to press territorial claims over India's Arunachal Pradesh state. Arguably, making China a central factor in the India-Australia relationship (a position which it seems to occupy in the India-Japan relationship) is likely to be more counterproductive than productive. 
Third, unlike some smaller states in the Indian Ocean region, Australia will not easily accede to India's desire to be recognized as the predominant naval power in the Indian Ocean (whether or not India is capable of realizing those ambitions). Australia will seek to extend the predominance of US naval power throughout the Indian Ocean region for as long as possible, while maintaining its position as one of the major naval powers on the Indian Ocean littoral. Australia's likely objective will be to mould India's ambitions in the Indian Ocean, so that India does not disregard the legitimate security concerns of littoral states and extra-regional powers. Whereas India and the United States may see benefit in controlling China's sea lanes of communication, Australia arguably has a greater interest in ensuring that China's security dilemma in the Indian Ocean is not worsened. This article argues that addressing China's security dilemma in the Indian Ocean will be crucial in avoiding heightened strategic competition on Australia's doorstep.

Fourth, the lack of an effective Indian Ocean multilateral framework may make any attempt to mould India's expectations in the Indian Ocean more difficult. Previous attempts to create regional fora spanning the Indian Ocean have not been successful. Australia might take a more active role in IONS, where India's exclusion of key extra-regional stakeholders, led it to be treated in Australia with a mild degree of skepticism or suspicion. One might also consider widening the terms of reference of the ASEAN Regional Forum to include the Indian Ocean (Buszynski 2009: 93). In any event, Australia's enthusiasm for building multilateral institutions in East Asia contrasts sharply with its neglect of the Indian Ocean.

In the coming years, Australia will need to play a careful three-way juggling act between the United States, China and India. Australia's relationships with each of them are very different. Australia's security relationship with the United States is crucial to Australia's security. Australia's relationship with China is now arguably crucial in economic terms and the significance of India may well grow to rival it. This means that Australia will need to carefully manage conflicts across its key economic, security and political relationships. In particular, it will be an important challenge for Australia to develop a security relationship 
with India that not only addresses areas of common interest but also allows Australia to help shape a potentially unstable security environment in the Indian Ocean.

\section{Notes}

1. The term originated in a 2005 report titled "Energy Futures in Asia" prepared for the US Secretary of Defence by the private consultants, Booz-Allen-Hamilton.

2. For detailed examinations of Chinese activities in the Indian Ocean, see Garver 2001 and Khurana 2008.

3. Thus a joke by a Chinese naval officer to his US counterpart that China should take responsibility for maritime security in the Western Pacific and the Indian Ocean was dutifully reported to the Indian press by Admiral Keating of the US Pacific Command (Pubby 2009).

4. Including an incident in $\mathbf{1 9 9 3}$ when Australian naval aircraft overflew an Indian aircraft carrier and in 1997 when the Australian navy dropped sonar buoys around the Indian destroyer INS Delhi, both of which elicited strong protests from New Delhi.

\section{References}

Australian Government, Defending Australia in the Asia Pacific Century: Force 2030 (Canberra: Commonwealth of Australia, 2009).

Beazley, Kim 1988 "The Two Ocean Navy" Paper presented at Seminar "The Indian Ocean Historical and Future Perspectives" Fremantle, 28 March.

Berlin, Donald L., 2006, "India in the Indian Ocean," Naval War College Review, Vol.59, No.2 (Spring), pp.58-89.

Bonnor, Jenelle, 2001, “Australia-India Security Relations: Common Interest or Common Disinterest?" Australian Defence Studies Centre Working Paper No.67. 
2008, "Australia - India: An Important Partnership" South Asian Survey

Vol.15, pp.165- 177.

Bonnor, Jenelle and Varun Sahni, 2004,“Australia - India Reengagement: Common Security Concerns, Converging Strategic Horizons, Complementary Force Structures," Australian Strategic Policy Institute Strategic Insights, October.

Brewster, David, 2010a, "The Australia - India Security Declaration: the Quadrilateral redux?" Security Challenges, Vol.6, No.1, pp.1-9.

David, 2010b, "An Indian sphere of influence in the Indian Ocean?" Security Challenges (forthcoming).

Buzsynski, Leszek , 2009, “Emerging Naval Rivalry in East Asia and the Indian Ocean: Implications for Australia," Security Challenges Vol.5 No.3, pp.73-93.

Chellaney, Brahma, 2007 “Dragon's Foothold in Gwadar” Asian Age, 7 April 2007.

Copley, Gregory R., 2009, Such a Full Sea: Australia's Options in a Changing Indian Ocean Region (Melbourne, Sid Harta Publishers).

Dikshit, Sandeep 2008, "No Strings Attached to Sale of Ships," The Hindu, 29 March Garver, John W., 2001, Protracted Contest: Sino-Indian Rivalry in the Twentieth Century (Seattle: University of Washington Press).

Gordon, Sandy, 2007, Widening Horizons: Australia's new relationship with India (Canberra: Australian Strategic Policy Institute).

Gurry, Meg, 1995 “Australian views of India: From Evatt to Evans” in Major General Dipankar Banerjee (ed.), Towards an Era of Cooperation: An Indo-Australian Dialogue (New Delhi: Institute for Defence Studies and Analyses), pp. 381 - 396. 1996, India: Australia's Neglected Neighbour? 1947 - 1996 (Griffith: Centre for the Study of Australia - Asia Relations). 
Hirama, Yoichi, 2004 "Japanese naval assistance and its effect on Australian-Japanese relations," in Phillips Payson O’Brien (ed.), The Anglo-Japanese Alliance, 1902-1922 (London: RoutledgeCurzon, 2004).

Holmes, James R. and Toshi Yoshihara, 2008a, “China's Naval Ambitions in the Indian Ocean" The Journal of Strategic Studies Vol.31, No.3 (June), pp.367-394.

,2008b, “India's 'Monroe Doctrine' and Asia's

Maritime Future," Strategic Analysis Vol.32, No.6 (November), pp.997- 1011

Holmes, James R., Andrew C. Winner and Toshi Yoshihara, 2009, Indian Naval Strategy in the 21st Century (London, Routledge).

Huxley, Tim, 1992, "India's naval expansion and Australia," Contemporary South Asia, Vol.1 No.33, pp.407-23.

India Defence, 2006 "Indian Navy awaits regional nod for patrolling Malacca Straits" www.india-defence.com, 7 June.

Indian Express, 21 April 2009.

Indian Navy, 2004, Indian Maritime Doctrine.

Khurana, Gurpeet S, 2008 “China's 'String of Pearls' in the Indian Ocean and its Security Implications," Strategic Analysis, Vol.32, No.1 (January), pp.1-39.

Lowe, Peter, 1997 "The Round table, the Dominions, and the Anglo-Japanese alliance, 1911-1922," The Round Table: The Commonwealth Journal of International Affairs, 1474029x, Volume 86, Issue 341, pp. 81 - 93

Medcalf, Rory, 2008, "Australia- India Relations: Hesitating on the Brink of Partnership," Asia Pacific Bulletin No.13, 3 April.

Medcalf, Rory and Amandeep Gill, 2009, “Unconventional Partners: Australia-India Cooperation in Reducing Nuclear Dangers" Lowy Institute Policy Brief October. 
Menon, Shiv Shankar, 2009, "Maritime Imperatives of Indian Foreign Policy," speech to the National Maritime Foundation, New Delhi, 11 September.

Mohan, C.Raja 2007, "India in East Asia” Australia-India Strategic Lecture, Melbourne, 21 February 2007.

Mukherjee, Hon Pranab and the Hon Stephen Smith, 2008, Joint Statement, 12 September. Natsukawa, Kazuya, 2006 "Opening Address, Indo-Japan Dialogue on Ocean Security," Tokyo, 12 October.

Panikkar, KM, 1943, The Future of South-East Asia (London: George Allen \& Unwin).

Pardesi, Marjeet Singh, 2005, Deducing India's Grand Strategy of Regional Hegemony from Historical and Conceptual Perspectives (Singapore: Institute of Defence and Strategic Studies, April).

People's Daily, 23 February 2010

Prakesh, Arun, 2006, "A Vision of India's Maritime Power in the 21st Century" USI Journal (July-September), pp 454-63.

Pubby, Manu, 2009, "China proposed division of Pacific, Indian Ocean regions, we declined: US Admiral" Indian Express, 15 May 2009.

Roberts, Frank and Varun Sahni, 2005, "The Australia - India bilateral relationship - current status and outstanding gaps," in Shared Interests: Australia-India relations into the twentyfirst century - Proceedings of the Australia-India Security Roundtable Canberra 11-12 April 2005 (Canberra: Australian Strategic Policy Institute).

Rudd, Kevin, 2009, "From fitful engagement to strategic partnership," Address to the Indian Council of World Affairs in New Delhi, 12 November.

Scott, David, 2006 "India's "Grand Strategy" for the Indian Ocean: Mahanian Visions," AsiaPacific Review, Vol. 13, No.2, pp.97-129. 
,2007, "India's Drive for a Blue Water Navy," Journal of Military and Strategic Studies, Vol. 10, No.2, pp.1-42.

Selth, Andrew, 2007 "Chinese Military Bases in Burma: The Explosion of a Myth" Regional Outlook Paper No.10, 2007 (Brisbane: Griffith University).

Sheridan, Greg, 2007 "Howard can make history with Indian alliance" The Australian, 19 April.

Singh, Manmohan, 2004 "PM's Address at the Combined Commander's Conference," 24 October.

Tellis, Ashley, 2002, "South Asia," in Richard J.Ellings and Aaron L.Friedberg (eds.) Strategic Asia 2001-02 Power and Purpose (Seattle: National Bureau of Asian Research), pp.262-3. Times of India, 13 April 2001.

Twining, Daniel, 2007 “America's Grand Design in Asia," The Washington Quarterly, Vol.30 No.3, pp.79-94.

Washington File, 2001, Powell Statement before Senate Foreign Relations Committee, 17 January 2001, <http://usinfo.org/wf-archive/2001/010117/epf301.htm>. 